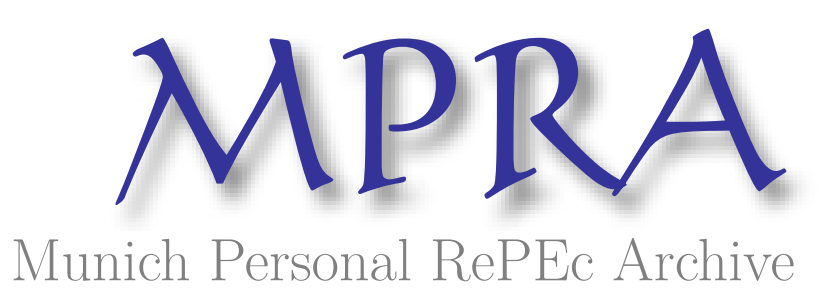

\title{
Corruption, political stability and illicit financial outflows in Sub-Saharan Africa
}

Orkoh, Emmanuel and Claassen, Carike and Blaauw, Phillip Frederick

North-West University. Potchefstroom Campus, South Africa

December 2017

Online at https://mpra.ub.uni-muenchen.de/89044/

MPRA Paper No. 89044, posted 19 Sep 2018 09:28 UTC 


\title{
Corruption, political stability and illicit financial outflows in Sub-Saharan Africa
}

\author{
Emmanuel Orkoh (NWU) \\ ORCID iD: http://orcid.org/0000-0002-0951-8936 \\ aorkoh@gmail.com \\ Carike Claassen (NWU) \\ carike.claassen@nwu.ac.za \\ Derick Blaauw (NWU) \\ derick.blaauw@nwu.ac.za
}

TRADE research focus area

Faculty of Economic and Management Sciences

North-West University

Potchefstroom campus

South Africa

\begin{abstract}
This paper examines the effect of corruption control and political stability on illicit financial outflows in Sub-Saharan Africa. We use a balanced panel data from the World Bank, United Nations Conference on Trade and Development and Global Financial Integrity on Sub-Saharan African countries covering the period 2005-2014. Our regression estimates reveal that a unit increase in political stability and corruption control reduce illicit financial outflow due to misinvoicing in merchandise trade by an average of US\$20.5 million and US\$ 44.3 million respectively. The results also show that high trade rating, financial sector rating and exchange rates reduce illicit financial outflows while increase in foreign direct investment and inflation increase illicit financial outflow. We recommend that governments in Sub-Saharan Africa countries must ensure that institutions responsible for fighting corruption and enhancing stable governance are well empowered and given the needed resources to work effectively to reduce corruption to the barest minimum.
\end{abstract}

Keywords: Corruption, political stability, illicit financial outflow, Sub-Saharan Africa JEL Classification: G11, G18, H26, P34, P45. 


\section{Introduction}

Agenda 2063 was introduced by the African Union in 2015 to serve as a roadmap to a transformed African continent within the next 50 years. Prominently, the Agenda issues a call to action on a variety of issues on which prompt action needs to be taken if its vision is to be fulfilled. Among the points listed is the call to "....[s]strengthen domestic resource mobilisation, build continental capital markets and financial institutions, and reverse the illicit flows of capital from the continent..." (AU, 2015a:18)

The focus on illicit capital flows is warranted, with Global Financial Integrity (GFI) estimating in 2013 that Africa is in fact a net creditor to the world, even after financial flows such as FDI, debt forgiveness and remittances have been taken into account. The African Union's (2015b:13) highlevel panel on illicit financial flows found that illicit financial flows were costing the African continent $\$ 50$ billion annually. Ndikumana (2017:2) shows that capital flight has reached particularly worrisome levels in the past decade, with $\mathbf{S} \$ 511$ billion being lost to capital flight between 2000 and 2010 as opposed to half that amount in the previous decade. These lost funds represent substantial opportunity cost for development efforts in Africa. Ndikumana (2014) shows that, between 2000 and 2010, if African countries had managed to retain capital lost to illicit flows and invest it in domestic economies, additional economic growth rates of as high as 3 per cent could have been achieved.

Research into capital flight in Africa has focused on trying to understand its determinants and possible impacts. A special issue of the African Development Review (ADR) (2016) delves into these issues at length. This paper responds to the research presented in that issue and contributes to the debate by examining the effect of corruption control and political stability on illicit financial outflows in Sub-Saharan Africa. The importance of good institutions and political stability were highlighted throughout the ADR's special issue as key drivers of capital flight in individual African countries (Geda \& Yimer, 2016; Gankou, Bendoma \& Sow, 2016; Ndiaye \& Siri, 2016; Kwaramba, Mahonye \& Mandishara, 2016). Mpenya, Metseyem \& Epo (2016:88) and Kwaramba et al. (2016:62) found that trade misinvoicing especially in the natural resource sector is an important channel of capital flight. This article makes a specific contribution to the foundations of the debate by looking at trade misinvoicing and Leakages in Balance of Payment (BOP) as sources of illicit financial outflows.

Whereas studies in the ADR focused on individual African countries, this article furthermore broadens the scope of the discourse through examining a panel of Sub-Saharan African countries and finds that the importance of political stability which was highlighted in several country level case studies holds at a continental level, too. It is found that a unit increase in political stability reduces capital flight in the form of merchandise trade misinvoicing by an average of $\$ 20.5$ million, while better corruption control reduces capital flight by an average of $\$ 44.3$ million. In 
contrast to Gankou et al.'s (2016:65) finding that there is no significant link between FDI inflows and illicit outflows, we do find that increased FDI increases illicit capital outflows. In the remainder of this paper, section 2 presents a brief literature review, followed by the research methodology in section 3 and a discussion of empirical results in section 4 . Section 5 concludes and makes tentative policy suggestions.

\section{Brief literature review}

Though much analysis has been done on the developmental impacts of capital flight, the literature on specific determinants of capital flight is sparse. Here, a brief summary of prominent studies is given. However, before presenting discussing these studies, it is important to distinguish between capital flight and illicit financial flows as the two terms are constantly used in this article. Global Financial Integrity (2017) defines such flows as illicit if the funds crossing borders are illegally earned, transferred, and/or utilized. If the flow breaks a law at any point, it is considered illicit. The difference in the calculation of capital flight and illicit flows lies in the way in which balance of payments leakages are estimated given that flows due to deliberate trade misinvoicing are common to both. Illicit financial flows are different from capital flight in the sense that capital flight includes both licit and illicit capital (Kar \& Spanjers, 2015). Licit capital flight is recorded and tracked, significantly lowering the probability that it has a corrupt or criminal source. In contrast, IFFs are by nature unrecorded, and cannot be used as public funds or private investment capital in their country of origin (Kar \& Spanjers, 2014). In this brief review, the terms capital flight and illicit financial flows are used interchangeably due to their inseparable nature. More so, empirical studies on illicit financial flows in particularly developing country are very limited.

Ndikumana, Boyce and Ndiaye (2014:37-39) provide a detailed overview of the issues relating to the measurement and drivers of capital flight. Their analysis of 39 African countries between 1970 and 2010 show that capital flight is fuelled by external borrowing and corroborate Murinde, Ochieng and Qingwei's (2014:15) finding that capital flight begets capital flight. Strong economic growth is shown to be a possible deterrent to capital flight. Other potential drivers of capital flight did not yield conclusive results, with no robust evidence that inflation, capital account openness, political regime or financial development drive capital flight (Ndikumana et el., 2016). The importance of institutional quality is highlighted once again, with results showing that even in natural resource rich countries, capital flight depends heavily on governance.

Ndikumana and Sarr (2016:13) delve more deeply into the relationship between capital flight and FDI inflows in Africa by applying dynamic panel methods to 32 African countries between 1970 and 2013. They do not find evidence that annual FDI inflows drive capital flight, though a positive relationship exists between FDI stocks and capital flight. The authors also find that natural resource endowments, especially oil, are positively related to capital flight and FDI stock. Institutional 
quality is found to have an important ameliorating effect on capital flight. A recurring theme in the literature is the key role that Institutions play in combatting high levels of capital flight.

The 2016 special issue of the $\mathrm{ADR}^{1}$ aims to fill the gap in literature by presenting eight countryspecific studies. The results vary according to country context though the importance of political stability and institutions are highlighted in various papers as key determinants of capital flight (Geda \& Yimer, 2016; Gankou, Bendoma \& Sow, 2016; Ndiaye \& Siri, 2016; Kwaramba, Mahonye \& Mandishara, 2016). Trade misinvoicing is found to be an important channel of capital flight (Ndikumana, 2016:2). The specific proxy of misinvoicing in a multi-country panel context has not been sufficiently addressed in the literature hence is the focus of the remainder of this study. The rest of the article commences with the methodology followed in our analysis.

\section{Methodology}

\subsection{Data sources and variable measurement}

The empirical analyses of this paper is based on a balanced panel data built from three sources: 1) the World Bank, 2) United Nations Conference on Trade and Development (UNCTAD), and 3) Global Financial Integrity (GFI). The data from the World Bank were extracted from the World Governance Indicators (WGI) and World Development Indicators (WDI). Variables extracted from the WGI are political stability and control of corruption. According the World Bank (2017), political stability and absence of violence/terrorism measures perceptions of the likelihood of political instability and/or politically-motivated violence, including terrorism. Similarly, control of corruption captures perceptions of the extent to which public power is exercised for private gain, including both petty and grand forms of corruption, as well as "capture" of the state by elites and private interests (World Bank, 2017). These variables are constructed from a list of individual variables from various data sources including the African Development Bank Country Policy and Institutional Assessments, Afrobarometer, Global Insight Business Conditions and Risk Indicators and Global Integrity Index ${ }^{2}$.

\footnotetext{
${ }^{1}$ Readers are referred to the full special edition for in-depth information on the literature and findings presented in case studies: Ndikumana, L. (ed) 2016. Supplement: AERC's project on "Capital flight from Africa." African Development Review, 28(S1):1-123.

${ }^{2}$ Details of the methodological approaches for constructing the indicators and sources of data have been discussed by the World Bank and it is accessible on http://info.worldbank.org/governance/wgi/index.aspx\#doc. The data on inflation can be accessed from the World Bank database at http://data.worldbank.org/indicator/FP.CPI.TOTL.ZG while the data on FDI are accessible at the FDI/MNE database (www.unctad.org/fdistatistics).
} 
From the WDI, the variables extracted for the analysis are exchange rate and inflation. According to the World Bank, inflation which is measured by the consumer price index reflects the annual percentage change in the cost to the average consumer of acquiring a basket of goods and services that may be fixed or changed at specified intervals, such as yearly. Similarly, exchange rate is calculated as an annual average based on monthly averages captured in local currency units relative to the U.S. dollar (World Bank, 2017). Aside these variables, foreign direct investment (FDI) inflows (measured in millions of dollars) were obtained from the UNCTAD interactive database for the countries and the period 2005 to 2014. The inclusion of these variables is to assess the effects of macrocosmic conditions and policies on illicit financial outflows in Sub-Saharan Africa (UNCTAD, 2017).

In addition to these explanatory variables, we extracted the data on illicit financial flows (IFFs) for the respective years and countries from the database of the Global Financial Integrity (GFI). The Global Financial Integrity (2017) explains that the measures of illicit financial flows stem from two sources: (1) deliberate misinvoicing in merchandise trade (the source of GFI's low and high estimates), and (2) leakages in the balance of payments (also known as "hot money flows"). However, comparing the two sources, trade misinvoicing is the primary measurable means by which organisations and individuals shift funds in and out of developing countries illicitly. The authors emphasis that using the lower estimates for trade misinvoicing alone produces an average of 87 percent of illicit financial outflows due to fraudulent misinvoicing of trade (Global Financial Integrity, 2017). Apart from these explanations, we also observed that data on "hot money flows had many missing observations most of the countries. This contributed to a drop in the number of countries from 37 to 29 compared to the 37 for the indicator of misinvoicing in merchandise trade. This however, did not affect the intuition sign and level of significance of the explanatory variables.

\subsection{Empirical estimation strategy}

Since panel data was used for the analysis, we explored the appropriateness of both random and fixed effect models by conducting the Hausman post estimation test. The null hypothesis of the Hausman test is that individual effects are uncorrelated with any regressor in the model against the alternative hypothesis that individual effects are significantly correlated with at least one regressor in the mode (Hausman, 1978; Park, 2011). The test suggested that the estimates of the random effect model must be preferred to those of the fixed effect. The effect random model is appropriate if there is enough reason to believe that differences across entities have some influence on the dependent variable(Torres-Reyna, 2007). As a result, we specify the random effect model as:

$Y_{i t}=B_{1} X_{i t}+\alpha_{0}+\mu_{i t}+\varepsilon_{i t}$

where $\alpha_{0}$ is the constant term, $\mu_{i t}$ is the between entity error, and $\varepsilon_{i t}$ is the within entity error. Similarly, $B_{1}$ is the vector of the coefficients and $X_{i t}$ is the vector of the explanatory variables 
including the variables of interest (control of corruption and political stability). From equation 1, the empirical estimation model can be specified as:

IFO $_{i t}=\beta_{1}$ Ccontrol $_{i t}+\beta_{2}$ Pstability $_{i t}+\beta_{3}$ Trating $_{i t}+\beta_{4}$ FSR $_{i t}+\beta_{5} F D I_{i t}+$ $\beta_{6}$ Exchangerate $_{i t}+\beta_{7}$ Inflation $_{i t}+\alpha_{0}+\mu_{i t}+\varepsilon_{i t}$

$\beta_{1}<0, \beta_{2}<0, \beta_{3}<0, \beta_{4}<0, \beta_{5}>0, \beta_{6}>0$ and $\beta_{7}>0$

In equation 2, IFO represents illicit financial outflows, Ccontrol represent corruption control, Pstability is the political stability and Trating represents trade rating of the country in question. In addition, FSR is the financial sector rating, Exchangerate and Inflation are respectively, exchange rate and inflation (consumer price index). This paper is theoretically underpinned by the investment diversion theory which holds that capital flight is influenced by two sets of forcesmacro economic and political uncertainty in developing countries and better investment opportunities in developed countries (Vukenkeng \& Mukete, 2016). Vukenkeng and Mukete (2016) explains that the better investment opportunities in developed nations is the outcome of high interest rate, a variety of financial instruments, political and economic stability, the nature of the tax policy and the keeping of secret accounts. These two sets of conditions serve as motivation factors for investors to move their investment or resources mostly illegally from less developed countries to advanced countries. Political instability and poor governance contribute to a domestic environment that deters investment and induces capital flight (Le \& Rishi, 2006). Based on this theoretical perspective, we expect corruption control and political stability to have negative association with illicit financial outflows. High rating of a country's political stability should significantly reduce illicit financial outflows.

The World Bank (2005) assert that in many developing economies, corruption works as a regressive tax which leads instances where the poor pay a disproportionate share of their income in the form of bribes to secure access to public services. Corruption has contributed to the failure of many aid-funded projects and it has the potential to weaken younger democracies (Kaufmann, 2003). Extant studies suggest that bribes and official extortion act as an extra tax which deter potential foreign direct investment into developing countries. Corruption also contributes to macroeconomic vulnerability and lower economic growth (Wei, 2002; Wei \& Wu, 2002). We therefore expect a negative relationship between corruption control and illicit financial outflow.

In addition to these variables, we expect that macroeconomic indicators such as high trade rating and financial sector rating to have negative association with illicit financial outflows since improvement in these variables are signs of robust institutional policies. On the basis of theoretical predictions and empirical findings, we expect that high inflation rate and increase in FDI should be associated with increase in illicit financial outflows. Extent literature on exchange rate capitalflight nexus suggests an element of reverse causality which makes a priori prediction of its effect on illicit financial outflows difficult and dependent on country specific context (Uguru, Ozor, \& Nkwagu, 2014). Country specific evidence in Nigeria, South Africa and Zambia shows that 
expected currency depreciation and appreciation have been major drivers of capital flight (Mbewe, 2015). We therefore expect that stronger exchange rate (appreciation of the local currency) should be associated with lower illicit financial outflows while weaker exchange rate (depreciation of the local currency) will be associated with high illicit financial outflows.

\section{Results and discussion}

As a starting point of the analysis, we present the results of a brief description of the trend of illicit outflows from the two sources (misinvoicing of trade in merchandise and leakages in balance of payment) and the explanatory variables of interest (control of corruption and political stability). The averages of the 10 percent high and 10 percent low for the two sources (misinvoicing in merchandise trade and leakages in balance of payment) of illicit financial outflows are presented in Table A2 at the appendix. The results show that across countries, illicit outflows are very high in countries such as Niger, Sudan, Sierra Leon and Nigeria but very low in Central African Republic, Eretria, and Guinea Bissau. Figure 1 depict that illicit financial outflows increased from 2004 to 2008 before decreasing between 2008 and 2010. However, from 2010 to 2014, the trend was alternating between the years. The upper estimates Illicit financial outflows (10 percent high) peaked to as high as US\$ 1890 million on average in 2008 but reduced to the lowest (US\$1100) in 2012. Although illicit financial outflow due to misinvoicing of merchandise trade has reduced since 2013, it still remains high at an average of about US\$ 900 million in 2014. It can be observed that illicit outflows due to leakages in the balance of payment follow the trend as the misinvoicing of trade in merchandise trade. The Figure generally shows that between 2006 and 2009, illicit financial outflows increased when ranking of corruption control and political stability were low. Similar phenomenon was observed between 2011 and 2014.

Figure 1: Misinvoicing in merchandise trade, political stability and corruption control

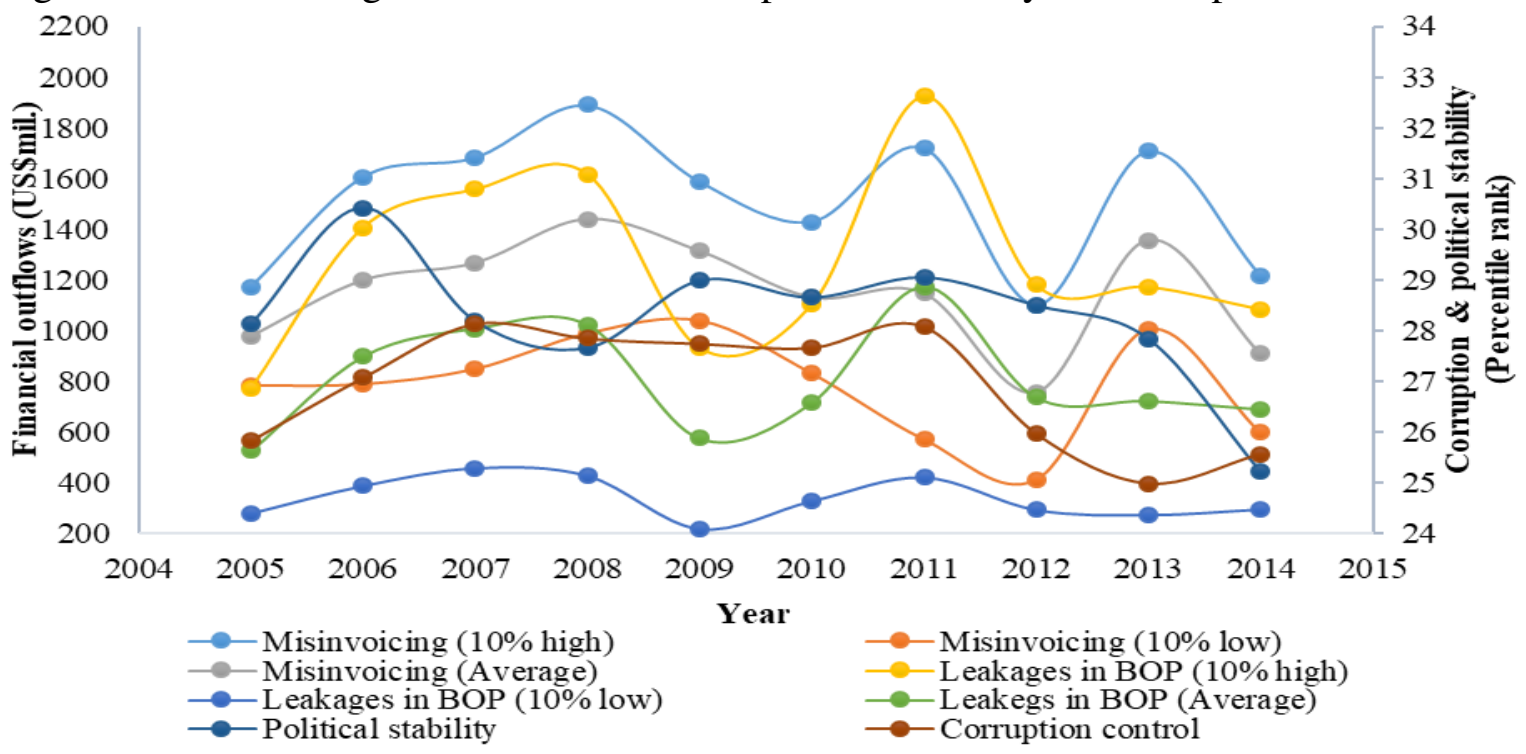

Source: Prepared by authors using data from World Bank and Global Financial Integrity 
Across countries, Table A2 at the appendix shows that Nigeria recorded the highest average amount of illicit financial outflows (US\$ 17855.95 million), followed by Sudan (US\$ 8905.085 million), Ethiopia (US\$2205.775 million) while Benin (US\$180.8223 million), Comoros (US\$ 44.2375 million), and Central African Republic (US\$ 29.7536 million) are among the countries that experienced the lowest amount of illicit financial outflows from 2005 to 2014. Figure 2 further shows that people's perception of corruption control and political stability in Sub-Saharan Africa have waned since 2011 and the trend was very pronounced in 2013. People's perception of political stability was high in 2006 but very low in 2014. Similarly, perception of corruption control was high in 2007 and 2011 after which there has been a downward trend. Observe that there is an element of association between corruption control, political stability and financial outflows. What is very conspicuous from the Figure is that at high levels of people's perception of corruption control and political stability, illicit financial outflows are low. This is particularly the case between 2007 and 2009 as well as 2011 and 2013.

Figure 2: Control of corruption and misinvoicing in merchandise trade by country

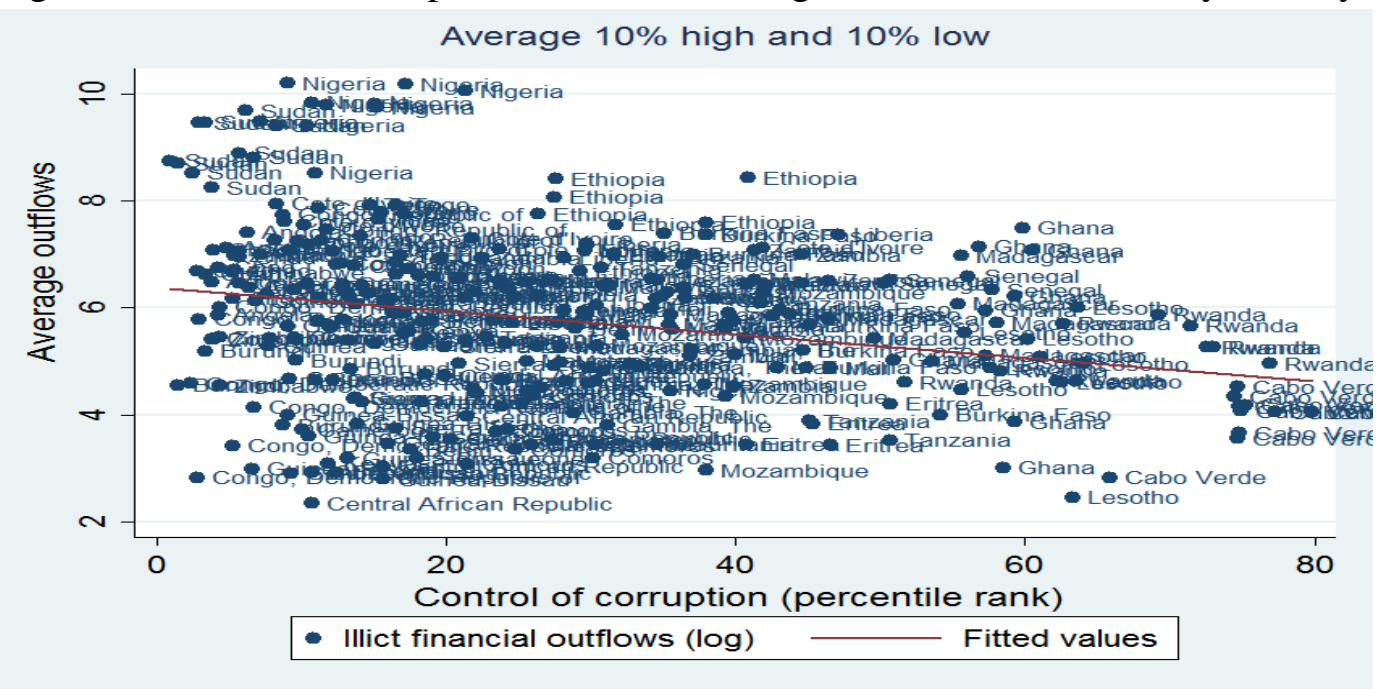

Source: Prepared by the authors using data World Bank and Global Financial Integrity

In addition to the trend analysis, we present bivariate regression results in Figures 2 and 3 taking into consideration the countries. In Figure 2, there is negative relationship between people's perception of corruption control and illicit financial outflows although there are some countries such as Central African Republic, Lesotho, Ethiopia, Carbo Verde, Congo Democratic Republic, Mozambique and Ghana that appear to be outliers. This means that if indeed corruption has any implications for illicit financial outflows, the governments of these countries would have to work to reduce corruption and maintain the confidence of their citizens. In Figure 3, a similar negative 
relationship is observed between political stability ${ }^{3}$ and illicit it financial outflows. The countries appear to be outliers in the Figure 2 also appear to be outliers in Figure 3. This brief descriptive analyses have shown that high levels of corruption control and political stability have negative association with illicit financial outflows. However, we did control for the effects of other variables on illicit financial outflows and those variables influence the effect of political stability and control of corruption ${ }^{4}$ on illicit financial outflows. The next section presents and discusses the results of the multivariate regression with regular references to the existing literature.

Figure 3: Political stability and misinvoicing in merchandise trade by country

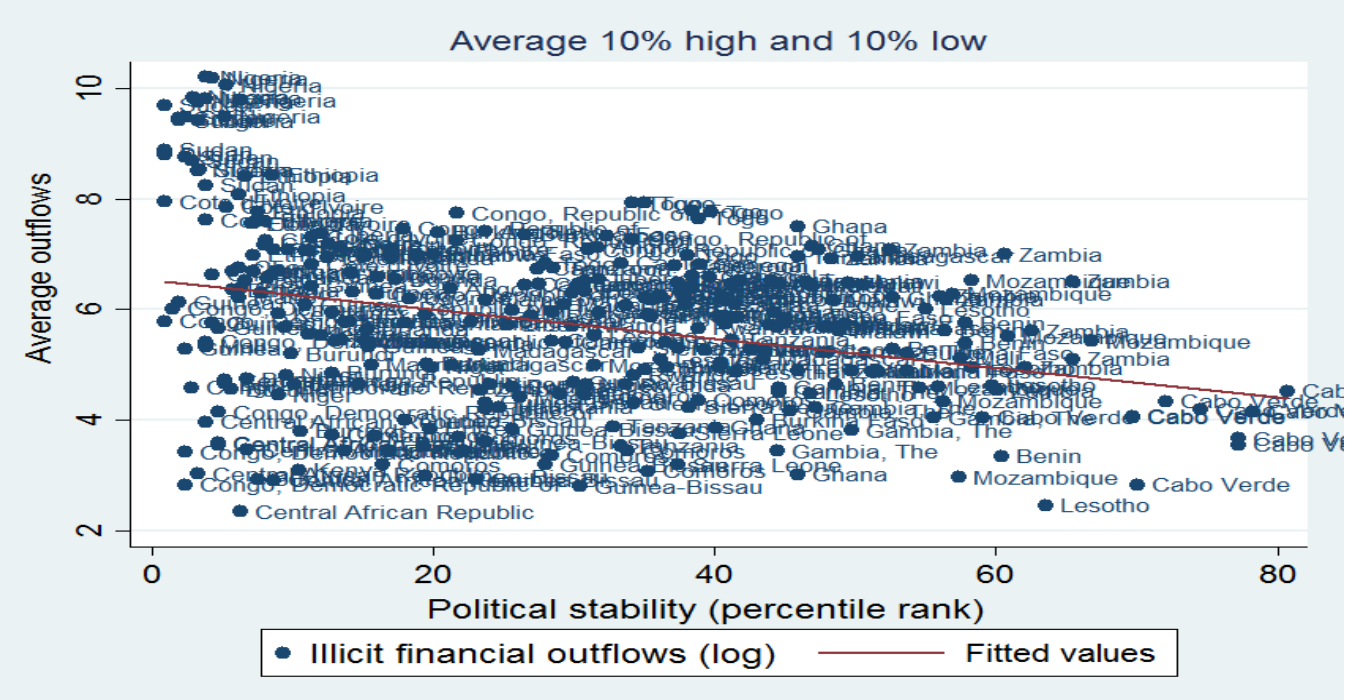

Source: Prepared by the authors using data World Bank and Global Financial Integrity

\subsection{Regression estimates}

In order to ascertain the reliability of the regression estimates, we present results of the Hausman post estimation tests for the choice between the fixed effects and random effects estimates at the bottom of each Table of the regression outputs. The null hypothesis is that the preferred model is random effects versus the alternative that the fixed effects are preferred to the random effects

\footnotetext{
${ }^{3}$ Political Stability and Absence of Violence/Terrorism measures perceptions of the likelihood of political instability and/or politically-motivated violence, including terrorism. Percentile rank indicates the country's rank among all countries covered by the aggregate indicator, with 0 corresponding to lowest rank, and 100 to highest rank. Percentile ranks have been adjusted to correct for changes over time in the composition of the countries covered by the WGI.

${ }^{4}$ Control of Corruption captures perceptions of the extent to which public power is exercised for private gain, including both petty and grand forms of corruption, as well as "capture" of the state by elites and private interests. Percentile rank indicates the country's rank among all countries covered by the aggregate indicator, with 0 corresponding to lowest rank, and 100 to highest rank. Percentile ranks have been adjusted to correct for changes over time in the composition of the countries covered by the World Governance Indicators (WGI).
} 
(Greene, 2008). The null hypothesis tests whether the unique errors terms are correlated with the regressors (Torres-Reyna, 2007). The results in all the three Tables show that the random effect estimates must be preferred to those of the fixed effect since the probability values of the Hausman tests are insignificant. However, we present the models of both fixed effect and random effect as well as the transformed and untransformed dependent variables for comparison purposes. It is also important to note that the dependent variables for the results presented in Tables 1, 2 and 3 are respectively 10 percent high of illicit financial outflows, 10 percent low of illicit financial outflows and the average of the two.

Table 1: Estimates of illicit financial outflows (10 percent high)

\begin{tabular}{lcccc}
\hline $\begin{array}{l}\text { Dependent variable } \\
\text { (Misinvoicing in trade) }\end{array}$ & $\begin{array}{c}\text { Fixed effect } \\
(\mathrm{US} \$ \mathrm{mil})\end{array}$ & $\begin{array}{c}\text { Fixed effect } \\
(\mathrm{log})\end{array}$ & $\begin{array}{c}\text { Random effect } \\
(\mathrm{US} \$ \mathrm{mil})\end{array}$ & $\begin{array}{c}\text { Random effect } \\
(\log )\end{array}$ \\
\hline Corruption control & $-36.54 * *$ & $-0.0151^{* *}$ & $-35.83 * *$ & $-0.0151^{* * *}$ \\
& $(15.91)$ & $(0.00585)$ & $(15.71)$ & $(0.00577)$ \\
Political stability & $-53.72 * * *$ & $-0.0131 * *$ & $-52.79 * * *$ & $-0.0127 * *$ \\
& $(16.18)$ & $(0.00595)$ & $(16.00)$ & $(0.00587)$ \\
Trade rating & -571.4 & -0.153 & $-611.8 *$ & -0.155 \\
& $(368.1)$ & $(0.135)$ & $(363.8)$ & $(0.133)$ \\
Financial sector rating & -4.145 & 0.000284 & -4.102 & -0.000492 \\
& $(13.02)$ & $(0.00478)$ & $(12.73)$ & $(0.00467)$ \\
Foreign direct investment & $737.7 * * *$ & $0.335 * * *$ & $687.8 * * *$ & $0.332 * * *$ \\
& $(124.7)$ & $(0.0458)$ & $(116.6)$ & $(0.0428)$ \\
Exchange rate & $-513.0 * * *$ & $-0.133 * * *$ & $-526.9 * * *$ & $-0.132 * * *$ \\
Inflation $(\mathrm{CPI})$ & $(104.1)$ & $(0.0382)$ & $(102.1)$ & $(0.0375)$ \\
& 214.9 & $0.142 *$ & 283.4 & $0.142 *$ \\
Constant & $(212.8)$ & $(0.0782)$ & $(202.0)$ & $(0.0741)$ \\
& $4,897 * * *$ & $6.015 * * *$ & $5,216 * * *$ & $6.026 * * *$ \\
Observations & $(1,629)$ & $(0.599)$ & $(1,578)$ & $(0.579)$ \\
R-squared & 302 & 302 & 302 & 302 \\
Wald chi2(1) & 0.321 & 0.314 & 0.3143 & 0.3139 \\
Prob > chi2 & ---- & ---- & 134.74 & 134.50 \\
Hausman test & ---- & ---- & 0.000 & 0.000 \\
Prob>chi2 & ---- & ---- & 2.05 & 0.93 \\
\hline Robust standard & ---- & 0.9572 & 0.9959 \\
\hline
\end{tabular}

Robust standard errors in parentheses; *** $\mathrm{p}<0.01, * * \mathrm{p}<0.05, * \mathrm{p}<0.1$

In Table1 (regression estimates of 10 percent high of outflows), it can be seen that at 1 percent level of significance, 1 percent increase in the corruption control score of a country reduces illicit financial outflows by about 1.5 percent which is equivalent to about US\$ 36 million. Similarly, a unit increase in the political stability score of a country reduces illicit financial outflows by about 
1.3 percent which also translate into an amount of US\$53 million. Table 2 shows an insignificant effect of corruption control on 10 percent low of illicit financial outflows in Sub-Saharan Africa although the intuition signs are correctly observed. With respect to political stability, the results depict that at 1 percent level of significance, an increase in a country's score of its political stability by 1 percent is associated with a reduction in illicit financial outflows by about 1.6 percent (US $\$$ 36 million).

The effects of political stability and corruption control on the average 10 percent high and 10 percent low of illicit financial outflows in Sub-Saharan Africa (see Table 3) are 1.25 percent (US\$ 20.48 million) and 1.29 percent (US\$ 44.26 million) respectively. These results corroborate the findings of earlier study conducted by Mossadak and Lahlou (2013) who concluded that good governance (measured by corruption control and political stability) in the public sector could reduce the illicit capital flight in the MENA region. The authors' asserted that these variables reinforce the confidence of economic agents in the national economic and financial system. It is therefore evident from the results of the present study and existing literature that the effort to address the issue of illicit financial flows from Sub-Saharan Africa require sustained politically stable environment and low level of corruption.

Aside political stability and corruption control, we assess the effects of other control variables on illicit financial outflows. Reports of the Global Financial Integrity (GFI) and UN regional economic commissions, including the Economic Commission for Latin America and the Caribbean (ECLAC) and the Economic Commission for Africa (UNECA) suggest that there is close relationship between illicit financial flows and trade of developing countries (Global Financial Integrity, 2017; United Nations, 2017). As a result, trade rating ${ }^{5}$ of the countries was included the models as a control variable. The results in Table 1 shows that improvement in the rating of a country by 1 percent reduces illicit outflows (10 percent high) by 15.5 percent (US $\$$ 611.8 million). The corresponding reduction for the 10 percent low (see Table 2) and average of 10 percent high and 10 percent low (Table 3 ) of outflows are respectively 28.5 percent (US\$ 231.7 million) and 20.0 percent (US\$ 421.8 million).

\footnotetext{
${ }^{5}$ Trade rating assesses how the policy framework fosters trade in goods on a scale of ( $1=$ low to $6=$ high). The data on trade rating were obtained from the World Bank Group, CPIA database (http://www.worldbank.org/ida).
} 
Table 2: Estimates of illicit financial outflows (10 percent low)

\begin{tabular}{|c|c|c|c|c|}
\hline $\begin{array}{l}\text { Dependent variable } \\
\text { (Misinvoicing trade) }\end{array}$ & $\begin{array}{l}\text { Fixed effect } \\
\text { (US\$ mil) }\end{array}$ & $\begin{array}{l}\text { Fixed effect } \\
\quad(\log )\end{array}$ & $\begin{array}{l}\text { Random effect } \\
\text { (US\$ mil) }\end{array}$ & $\begin{array}{c}\text { Random effect } \\
(\log )\end{array}$ \\
\hline Corruption control & $\begin{array}{l}-4.602 \\
(12.69)\end{array}$ & $\begin{array}{l}-0.00408 \\
(0.00515)\end{array}$ & $\begin{array}{l}-5.123 \\
(12.57)\end{array}$ & $\begin{array}{l}-0.00422 \\
(0.00512)\end{array}$ \\
\hline Political stability & $\begin{array}{c}-36.71 * * * \\
(12.91)\end{array}$ & $\begin{array}{c}-0.0160 * * * \\
(0.00524)\end{array}$ & $\begin{array}{c}-35.74 * * * \\
(12.80)\end{array}$ & $\begin{array}{c}-0.0155^{* * * *} \\
(0.00521)\end{array}$ \\
\hline Trade rating & $\begin{array}{l}-192.2 \\
(293.6)\end{array}$ & $\begin{array}{c}-0.273 * * \\
(0.119)\end{array}$ & $\begin{array}{l}-231.7 \\
(291.1)\end{array}$ & $\begin{array}{c}-0.285^{* *} \\
(0.118)\end{array}$ \\
\hline Financial sector rating & $\begin{array}{c}0.374 \\
(10.38)\end{array}$ & $\begin{array}{r}-0.000963 \\
(0.00421)\end{array}$ & $\begin{array}{l}-1.189 \\
(10.19)\end{array}$ & $\begin{array}{l}-0.00202 \\
(0.00415)\end{array}$ \\
\hline Foreign direct investment & $\begin{array}{c}563.0 * * * \\
(99.42)\end{array}$ & $\begin{array}{l}0.374 * * * \\
(0.0404)\end{array}$ & $\begin{array}{c}497.7 * * * \\
(93.31)\end{array}$ & $\begin{array}{l}0.355^{* * * *} \\
(0.0380)\end{array}$ \\
\hline Exchange rate & $\begin{array}{l}-134.7 \\
(82.99)\end{array}$ & $\begin{array}{c}-0.0767 * * \\
(0.0337)\end{array}$ & $\begin{array}{l}-152.9^{*} \\
(81.70)\end{array}$ & $\begin{array}{c}-0.0799 * * \\
(0.0332)\end{array}$ \\
\hline Inflation rate (CPI) & $\begin{array}{l}56.07 \\
(169.7)\end{array}$ & $\begin{array}{c}0.113 \\
(0.0689)\end{array}$ & $\begin{array}{c}119.2 \\
(161.6)\end{array}$ & $\begin{array}{l}0.132 * * \\
(0.0658)\end{array}$ \\
\hline Constant & $\begin{array}{c}370.5 \\
(1,300)\end{array}$ & $\begin{array}{c}5.013 * * * \\
(0.527)\end{array}$ & $\begin{array}{c}847.4 \\
(1,263)\end{array}$ & $\begin{array}{c}5.134 * * * * \\
(0.514)\end{array}$ \\
\hline Observations & 302 & 302 & 302 & 302 \\
\hline R-squared & 0.190 & 0.366 & 0.1775 & 0.3577 \\
\hline Wald chi2(1) & ---- & ---- & 63.44 & 163.75 \\
\hline Prob > chi2 & ---- & ---- & 0.0000 & 0.0000 \\
\hline Hausman test & ---- & ---- & 4.12 & 4.61 \\
\hline Prob > chi2 & ---- & ---- & 0.7655 & 0.7069 \\
\hline
\end{tabular}

Standard errors in parentheses; $* * * \mathrm{p}<0.01, * * \mathrm{p}<0.05, * \mathrm{p}<0.1$

The extent of development of the financial sector of the respective countries is expected to have significant influence on illicit financial outflows (Geda \& Yimer, 2016). A well-developed financial sector may have both positive and negative effects depending on the adherence of the banks to the existing laws and rules guiding the transfer of funds outside and inside the country. Although there is limited literature on how banks actually operate as facilitators of illicit financial flows in Africa, there is evidence that banks play an active role in facilitating capital flight from continent (Heggstad \& Fjeldstad, 2010). In this study we find that increase in the financial sector rating ${ }^{6}$ reduces the illicit financial outflows although the results are insignificant in all the models. Trade rating and financial sector development can be classified as institutional assessment

\footnotetext{
${ }^{6}$ Financial sector rating is an assessment of the structure of the financial sector and the policies and regulations that affect it on a scale of (1=low to $6=$ high). Data on financial sector rating were obtained from the World Bank Group, CPIA database (http://www.worldbank.org/ida).
} 
variables. It is therefore evident from these results that robustness of intuitional policies is relevant for the control of illicit financial outflows in Sub-Saharan African countries. The development of a robust financial sector capable of tracking financial flows and as well as effective trade policies are essential for the achievement of the objective addressing illicit financial flows.

Table 3: Estimates of illicit financial outflows (10 percent high and low)

\begin{tabular}{lcccc}
\hline $\begin{array}{l}\text { Dependent variable } \\
\text { (Misinvoicing in trade) }\end{array}$ & $\begin{array}{c}\text { Fixed effect } \\
(\text { US } \$ \mathrm{mil})\end{array}$ & $\begin{array}{c}\text { Fixed effect } \\
(\mathrm{log})\end{array}$ & $\begin{array}{c}\text { Random effect } \\
(\text { US } \$ \mathrm{mil})\end{array}$ & $\begin{array}{c}\text { Random effect } \\
(\mathrm{log})\end{array}$ \\
\hline Corruption control & -20.57 & $-0.0125^{* *}$ & -20.48 & $-0.0125^{* *}$ \\
& $(13.46)$ & $(0.00555)$ & $(13.31)$ & $(0.00548)$ \\
Political stability & $-45.22^{* * *}$ & $-0.0133^{* *}$ & $-44.26^{* * *}$ & $-0.0129^{* *}$ \\
& $(13.68)$ & $(0.00565)$ & $(13.55)$ & $(0.00558)$ \\
Trade rating & -381.8 & -0.196 & -421.8 & -0.200 \\
& $(311.3)$ & $(0.128)$ & $(308.2)$ & $(0.127)$ \\
Financial sector rating & -1.885 & -0.000193 & -2.646 & -0.00106 \\
& $(11.01)$ & $(0.00454)$ & $(10.79)$ & $(0.00444)$ \\
Foreign direct investment & $650.4^{* * *}$ & $0.348^{* * *}$ & $592.7^{* * *}$ & $0.340^{* * *}$ \\
& $(105.4)$ & $(0.0435)$ & $(98.78)$ & $(0.0407)$ \\
Exchange rate & $-323.9 * * *$ & $-0.118^{* * *}$ & $-339.9^{* * *}$ & $-0.118^{* * *}$ \\
& $(87.99)$ & $(0.0363)$ & $(86.48)$ & $(0.0356)$ \\
Inflation (CPI) & 135.5 & $0.136^{*}$ & 201.3 & $0.142^{* *}$ \\
& $(179.9)$ & $(0.0742)$ & $(171.1)$ & $(0.0705)$ \\
Constant & $2,629^{*}$ & $5.696^{* * *}$ & $3,027^{* *}$ & $5.736^{* * *}$ \\
& $(1,378)$ & $(0.568)$ & $(1,337)$ & $(0.551)$ \\
\hline Observations & 302 & 302 & 302 & 302 \\
R-squared & 0.283 & 0.335 & 0.2732 & 0.3339 \\
Wald chi2(1) & ---- & ---- & 110.50 & 147.38 \\
Prob > chi2 & ---- & ---- & 0.0000 & 0.0000 \\
Hausman test & ---- & --- & 3.04 & 1.36 \\
Prob > chi2 & ---- & ---- & 0.8812 & 0.9868 \\
\hline
\end{tabular}

Robust standard errors in parentheses; *** $\mathrm{p}<0.01,{ }^{* *} \mathrm{p}<0.05,{ }^{*} \mathrm{p}<0.1$

In addition to trade rating, and financial sector rating, the results show that an increase in foreign direct investment (FDI) inflow has a positive effect on illicit financial outflows in Sub-Saharan Africa. A percentage increase in FDI increases illicit financial outflows (10 percent high) by 33 percent (US\$ 687.8 million). For the 10 percent low, the estimates are 35.5 percent (US\$ 497.7 million) while those for the average of the 10 percent high and 10 percent low are 34 percent (US\$ 592.7 million). In this study, we considered only FDI inflows and not the net because the inflows are expected to generate the capital or funds that the investors may expatriate illegally outside their countries of operation. Including the outflow or the net flow will amount to double counting since 
the outflows may also contain some element of illicit outflows. In fact, our findings on the percent increase in illicit financial outflows fall within the range of 31 to 40 percentage increase in capital flight as observed by (Kant, 1996).

Table 4: Illicit financial outflow due leakage in BOP (10 percent high)

\begin{tabular}{lcccc}
\hline Dependent variable & Fixed effect & Fixed effect & Random effect & Random effect \\
\cline { 2 - 5 } Illicit financial outflows & $(\mathrm{US} \$$ mil) & $(\log )$ & $(\mathrm{US} \$ \mathrm{mil})$ & $(\mathrm{log})$ \\
\hline Corruption control & $-32.79 * * *$ & -0.00931 & $-32.23 * * *$ & -0.00943 \\
& $(12.09)$ & $(0.00737)$ & $(11.95)$ & $(0.00728)$ \\
Political stability & $-48.93 * * *$ & $-0.0311^{* * *}$ & $-48.13 * * *$ & $-0.0304 * * *$ \\
& $(12.71)$ & $(0.00775)$ & $(12.53)$ & $(0.00764)$ \\
Trade rating & -23.06 & -0.189 & -34.67 & -0.195 \\
& $(304.6)$ & $(0.186)$ & $(299.2)$ & $(0.183)$ \\
Financial sector rating & -8.835 & -0.000119 & -6.618 & 0.000316 \\
& $(9.269)$ & $(0.00565)$ & $(9.046)$ & $(0.00553)$ \\
Foreign direct investment & $346.7 * * *$ & $0.287 * * *$ & $339.5 * * *$ & $0.287 * * *$ \\
& $(114.2)$ & $(0.0696)$ & $(109.1)$ & $(0.0671)$ \\
Exchange rate & $-843.8 * * *$ & $-0.291 * * *$ & $-839.1 * * *$ & $-0.288 * * *$ \\
Inflation (CPI) & $(115.1)$ & $(0.0702)$ & $(114.0)$ & $(0.0695)$ \\
Constant & 92.67 & -0.122 & 139.1 & -0.108 \\
& $(211.6)$ & $(0.129)$ & $(198.3)$ & $(0.123)$ \\
\hline Observations & $6,496 * * *$ & $7.801 * * *$ & $6,416 * * *$ & $7.761 * * *$ \\
R-squared & $(1,357)$ & $(0.827)$ & $(1,313)$ & $(0.808)$ \\
F-statistic/Wald chi2(1) & 267 & 267 & 267 & 267 \\
Prob > F/Prob>chi2 & 0.360 & 0.285 & 0.2803 & 0.2804 \\
Hausman test & 20.05 & 14.24 & 178.81 & 101.54 \\
Prob>chi2 & --0000 & 0.0000 & 0.0000 & 0.0000 \\
\hline Standard eros & ------ & ------ & 0.9724 & 0.9994 \\
\hline
\end{tabular}

Standard errors in parentheses; $* * * \mathrm{p}<0.01, * * \mathrm{p}<0.05, * \mathrm{p}<0.1$

It is also observed that an increase in inflation (measured by the consumer price index) is associated with an increase in illicit financial outflows in Sub-Saharan African countries. Inflation increases illicit financial outflows by an average of 14 percent which translates into an amount of about US\$ 201 million. This result is intuitively acceptable and expected in the sense that high inflation signals high interest rate (due to the positive association between the two variables) and consequently, a sign of unfavourable investment environment. This may serve as a motivation for risk averse investors to engage in illicit financial outflows. Contrary to the effect of inflation, higher exchange rate appears to reduce illicit financial outflows. Observe from Table 3 that at 1 percent level of significance, a percentage increase in the exchange rate reduces illicit outflows 
(10 percent high and 10 percent low) by 11.8 percent (US\$ 339.9 million). Similar significantly negative associations are observed for the 10 percent low and 10 percent high of illicit financial outflows in Tables 1 and 2.

Table 5: Illicit financial outflow due leakage in BOP (10 percent low)

\begin{tabular}{|c|c|c|c|c|}
\hline \multirow{2}{*}{$\begin{array}{l}\text { Dependent variable } \\
\text { Illicit financial outflows }\end{array}$} & \multirow{2}{*}{$\frac{\text { Fixed effect }}{\text { (US\$ mil) }}$} & \multirow{2}{*}{$\frac{\text { Random effect }}{(\log )}$} & \multirow{2}{*}{$\begin{array}{c}\text { Fixed effect } \\
\text { (US\$ mil) }\end{array}$} & \multirow{2}{*}{$\frac{\text { Random effect }}{(\log )}$} \\
\hline & & & & \\
\hline \multirow[t]{2}{*}{ Corruption control } & $-3.706^{*}$ & -0.00204 & $-3.664 *$ & -0.00211 \\
\hline & $(2.008)$ & $(0.00580)$ & $(2.004)$ & $(0.00572)$ \\
\hline \multirow[t]{2}{*}{ Political stability } & $-10.67 * * *$ & $-0.0262 * * *$ & $-10.39 * * *$ & $-0.0259 * * *$ \\
\hline & $(2.110)$ & $(0.00610)$ & $(2.103)$ & $(0.00600)$ \\
\hline \multirow[t]{2}{*}{ Trade rating } & -83.08 & $-0.372 * *$ & $-93.26^{*}$ & $-0.379 * * *$ \\
\hline & $(50.59)$ & $(0.146)$ & $(50.28)$ & $(0.144)$ \\
\hline \multirow[t]{2}{*}{ Financial sector rating } & -1.298 & -0.00164 & -1.123 & -0.00150 \\
\hline & $(1.539)$ & $(0.00445)$ & $(1.524)$ & $(0.00435)$ \\
\hline \multirow[t]{2}{*}{ Foreign direct investment } & $115.9 * * *$ & $0.298 * * *$ & $108.3 * * *$ & $0.293 * * *$ \\
\hline & $(18.96)$ & $(0.0548)$ & $(18.50)$ & $(0.0527)$ \\
\hline \multirow[t]{2}{*}{ Exchange rate } & $-103.1 * * *$ & $-0.160 * * *$ & $-102.7 * * *$ & $-0.159 * * *$ \\
\hline & $(19.12)$ & $(0.0553)$ & $(19.11)$ & $(0.0546)$ \\
\hline \multirow[t]{2}{*}{ Inflation (CPI) } & $-75.69 * *$ & $-0.191 *$ & $-59.31 *$ & $-0.181 *$ \\
\hline & $(35.14)$ & $(0.102)$ & $(33.82)$ & $(0.0964)$ \\
\hline \multirow[t]{2}{*}{ Constant } & $1,152 * * *$ & $6.624 * * *$ & $1,188 * * *$ & $6.642 * * *$ \\
\hline & $(225.4)$ & $(0.651)$ & $(222.7)$ & $(0.635)$ \\
\hline Observations & 267 & 267 & 267 & 267 \\
\hline R-squared & 0.423 & 0.323 & 0.4017 & 0.3196 \\
\hline F-statistic/Wald chi2(1) & 26.18 & 17.03 & 178.81 & 122.18 \\
\hline Prob $>$ F/Prob $>$ chi 2 & 0.000 & 0.0000 & 0.0000 & 0.0000 \\
\hline Hausman test & ------ & ------ & 11.25 & 0.25 \\
\hline Prob>chi2 & ------ & ------ & 0.1279 & 0.9999 \\
\hline
\end{tabular}

Standard errors in parentheses; $* * * \mathrm{p}<0.01, * * \mathrm{p}<0.05, * \mathrm{p}<0.1$

Similar to misinvoicing in merchandise trade, the results on leakages in the balance of payments (see Table 4) show that both political stability and corruption control have negative effects. Holding all other variables constant, an increase in the percentile rank of a country's corruption control by 1 reduces illicit financial outflows by US $\$ 3.664$ million ( 0.00943 percent) while the effect of political stability is US\$10.39 (0.0304 percent). In Tables 5 (10 percent low) and 6 (average of 10 percent low and 10 percent high) the effects are US\$ 3.664 million and US\$ 17.93 million respectively. Compared to the misinvoicing in merchandise trade, the effect of leakages in balance payment are lower. This confirms the claim by Global Financial Integrity (2017) that trade 
misinvoicing is the primary measurable means by which organisations and individuals shift funds in and out of developing countries illicitly.

Table 6: Illicit financial outflow due leakage in BOP (10 percent low)

\begin{tabular}{|c|c|c|c|c|}
\hline $\begin{array}{l}\text { Dependent variable } \\
\text { Illicit financial outflows } \\
\text { (Leakages in BOP) }\end{array}$ & Fixed effect & Random effect & Fixed effect & Random effect \\
\hline Corruption control & $\begin{array}{c}-18.25^{* * * *} \\
(6.758)\end{array}$ & $\begin{array}{l}-0.00799 \\
(0.00671)\end{array}$ & $\begin{array}{c}-17.93 * * * \\
(6.694)\end{array}$ & $\begin{array}{l}-0.00803 \\
(0.00662)\end{array}$ \\
\hline Political stability & $\begin{array}{c}-29.80 * * * \\
(7.103)\end{array}$ & $\begin{array}{c}-0.0288 * * * \\
(0.00706)\end{array}$ & $\begin{array}{c}-29.20 * * * \\
(7.017)\end{array}$ & $\begin{array}{c}-0.0285 * * * \\
(0.00695)\end{array}$ \\
\hline Trade rating & $\begin{array}{l}-53.07 \\
(170.3)\end{array}$ & $\begin{array}{l}-0.244 \\
(0.169)\end{array}$ & $\begin{array}{l}-66.26 \\
(167.6)\end{array}$ & $\begin{array}{l}-0.246 \\
(0.166)\end{array}$ \\
\hline Financial sector rating & $\begin{array}{l}-5.067 \\
(5.180)\end{array}$ & $\begin{array}{l}-0.000534 \\
(0.00515)\end{array}$ & $\begin{array}{l}-3.826 \\
(5.067)\end{array}$ & $\begin{array}{l}-0.000257 \\
(0.00504)\end{array}$ \\
\hline Foreign direct investment & $\begin{array}{c}231.3 * * * \\
(63.80)\end{array}$ & $\begin{array}{c}0.279 * * * \\
(0.0634)\end{array}$ & $\begin{array}{c}222.2 * * * \\
(61.11)\end{array}$ & $\begin{array}{c}0.281 * * * \\
(0.0612)\end{array}$ \\
\hline Exchange rate & $\begin{array}{c}-473.4 * * * \\
(64.35)\end{array}$ & $\begin{array}{c}-0.252 * * * \\
(0.0639)\end{array}$ & $\begin{array}{c}-470.8 * * * \\
(63.87)\end{array}$ & $\begin{array}{c}-0.250 * * * \\
(0.0631)\end{array}$ \\
\hline Inflation(CPI) & $\begin{array}{c}8.495 \\
(118.3)\end{array}$ & $\begin{array}{l}-0.130 \\
(0.118)\end{array}$ & $\begin{array}{c}43.31 \\
(111.0)\end{array}$ & $\begin{array}{l}-0.126 \\
(0.112)\end{array}$ \\
\hline Constant & $\begin{array}{c}3,824 * * * \\
(758.5)\end{array}$ & $\begin{array}{c}7.459 * * * \\
(0.754)\end{array}$ & $\begin{array}{c}3,811 * * * \\
(735.7)\end{array}$ & $\begin{array}{c}7.427 * * * \\
(0.737)\end{array}$ \\
\hline Observations & 267 & 267 & 267 & 267 \\
\hline R-squared & 0.385 & 0.299 & 0.3778 & 0.2969 \\
\hline F-statistic/Wald chi2(1) & 22.35 & 15.24 & 157.29 & 109.78 \\
\hline Prob $>$ F/Prob $>$ chi 2 & 0.0000 & 0.0000 & 0.0000 & 0.0000 \\
\hline Hausman test & ------ & ------ & 2.42 & 0.17 \\
\hline Prob $>$ chi 2 & ------ & ------ & 0.9333 & 1.0000 \\
\hline
\end{tabular}

We observe from the estimates in Tables 4, 5 and 6 that the intuitions signs are the same as those observed for the misinvoicing in merchandise trade although the magnitude of the effects are lower. Unlike the models for misinvoicing in merchandise trade, inflation appears to have a negative relationship with leakages in leakages in balance of payment. Our results are in contrast to those obtained by Le and Rishi (2006) who found positive relationship between inflation and capital out flight. These differences in direction of relationship could be due to a number of direct and indirect factors including the method of computing the leakages and the implication of inflation for trade balance which consequently influence the leakages. According to the Global Financial Integrity (2017), leakages from the balance of payments are the Net Errors and 
Omissions (NEO) term in the International Monetary Fund's (IMF) Balance of Payments Statistics (BOP) database. If in the course of computing the leakages, there are missing values for NEO in the BOP database, they attempt to fill the gaps with net errors and omissions data from various IMF country reports. This and many other factors may contribute to the observed negative effect.

\section{Conclusion}

This article builds on the pioneering contribution to the literature from various single country case studies on the determinants of capital flight. The role of institutions in combatting capital flight is well established in the literature. This article broadens the scope of the discourse through examining a panel of Sub-Saharan African countries and focusing on the role of misinvoicing as a proxy for capital flight in this discourse. We found that the importance of political stability which was highlighted in several country level case studies holds at a continental level, too. It is found that a unit increase in political stability reduces capital flight in the form of merchandise trade misinvoicing by an average of $\$ 20.5$ million, while better corruption control reduces capital flight by an average of $\$ 44.3$ million. In contrast to Gankou et al.'s (2016:65) finding that there is no significant link between FDI inflows and illicit outflows, we do find that increased FDI increases illicit capital outflows. The results furthermore show that high trade rating, financial sector rating and exchange rates reduce illicit financial outflows while increase in foreign direct investment and inflation increase illicit financial outflow.

The recommendation flowing from the results is unambiguous. Governments in Sub-Saharan Africa countries must ensure that institutions responsible for fighting corruption and enhancing stable governance are well empowered and given the needed resources to work effectively to reduce corruption to the barest minimum. More than lip service to good institutions is vital if the continent is to achieve the Agenda 2063 goals of a transformed African continent within the next 50 years. 


\section{References}

African Union. (2015a). Agenda 2063: The Africa we want. Addis Ababa: AUC.

African Union. (2015b). Illicit Financial Flows. Report of the High Level Panel on Illicit Financial Flows from Africa. Addis Ababa: UNECA.

Gankou, J.M., Bendoma, M. \& Sow, M.N. (2016). The institutional environment and the link between capital flows and capital flight in Cameroon. African Development Review, 28(S1):65-87.

Geda, A., \& Yimer, A. (2016). Capital Flight and its Determinants: The Case of Ethiopia. African Development Review, 28(S1), 39-49.

Global Financial Integrity. (2017). Illicit Financial Flows to and from Developing Countries: 2005-2014. Washington, D.C. : Global Financial Integrity.

Greene, W. H. (2008). Econometric analysis (6 ed.). Upper Saddle River, NJ: Pearson Prentice Hall.

Hausman, J. A. (1978). Specification tests in econometrics. Econometrica: Journal of the Econometric Society, 1251-1271.

Heggstad, K., \& Fjeldstad, O.-H. (2010). How banks assist capital flight from Africa: A literature review. CMI Report, 2010(6).

Kant, C. (1996). Foreign Direct Investment and Capital Flight. Princeton Studies on International Finance No. 80. Princeton, New Jersey: Princeton University.

Kar, D., \& Spanjers, J. (2014). Illicit Financial Flows from Developing Countries, 2003-2012. Washington, DC: Global Financial Integrity.

Kar, D., \& Spanjers, J. (2015). Flight capital and illicit financial flows to and from Myanmar: 1960-2013.

Kaufmann, D. (2003). Rethinking Governance: Empirical Lessons Challenge Orthodoxy. Social Science Research Network (SSRN). doi:http://dx.doi.org/10.2139/ssrn.386904

Le, Q. V., \& Rishi, M. (2006). Corruption and capital flight: An empirical assessment. International Economic Journal, 20(4), 523-540.

Mbewe, S. (2015). Capital flight and the role of exchange rates in Nigeria, South Africa and Zambia. University of Cape Town.

Mossadak, A., \& Lahlou, K. (2013). Empirical investigation on the illicit financial flows from MENA region. British Journal of Social Sciences, 1(9), 1-11.

Park, H. M. (2011). Practical guides to panel data modeling: a step-by-step analysis using stata. Public Management and Policy Analysis Program, Graduate School of International Relations, International University of Japan.

Torres-Reyna, O. (2007). Panel data analysis fixed and random effects using Stata (v. 4.2). Data \& Statistical Services, Priceton University.

Uguru, L. C., Ozor, B. M., \& Nkwagu, C. C. (2014). Capital Flight and Exchange Rate Volatility in Nigeria:The Nexus. Research Journal of Finance and Accounting, 5(16), 27-36. 
UNCTAD. (2017). FDI/MNE database. Retrieved July 31, 2017 from UNCTAD: www.unctad.org/fdistatistics

United Nations. (2017). World Economic Situation and Prospects 2017. New York: United Nations.

Vukenkeng, A. W., \& Mukete, E. M. (2016). Capital Flight and Economic Development: The Experience of Cameroon. Economics, 5(5), 64-72. doi:doi: 10.11648/j.eco.20160505.11

Wei, S.-J. (2002). Valuing governance: the corruption premium in global capital flows, in R. Litan, M. Pomerleano \& S. Vasudevan (eds) Financial Sector Governance:The Roles of the Public and Private Sectors. Washington, DC: Brookings Institution Press.

Wei, S.-J., \& Wu, Y. (2002). Negative alchemy? Corruption, composition of capital flows, and currency crises Preventing currency crises in emerging markets (pp. 461-506): University of Chicago Press.

World Bank. (2017). World development indicators on online (WDI) database. Retrieved July 31 , 2017 from World Bank: http://www.worldbank.org 


\section{Appendix}

Table A1: Summary statistics of the variables of interest

\begin{tabular}{|l|l|l|l|l|l|}
\hline Variable & Obs. & Mean & Std. Dev. & Min & Max \\
\hline Misinvoicing (10\% high) & 370 & 1788.42 & 4518.037 & 0.5392 & 29226.85 \\
\hline Misinvoicing (10\% low) & 370 & 937.067 & 3300.623 & 10.24 & 26744.9 \\
\hline Misinvoicing (average of low \& high) & 370 & 1357.74 & 3717.279 & 0.3898 & 26734.89 \\
\hline Leakages in BOP (10\% high) & 290 & 1297.76 & 3300.901 & 0.0000 & 28469.21 \\
\hline Leakages in BOP (10\% low) & 290 & 337.71 & 579.4209 & 0.0000 & 4551.055 \\
\hline Leakages in BOP (average of low \& high) & 290 & 817.736 & 1883.523 & 0.0000 & 15345.59 \\
\hline Corruption control (percentile rank) & 370 & 28.4941 & 19.0119 & 0.9479 & 79.8077 \\
\hline Political stability (percentile rank) & 370 & 28.8782 & 19.5051 & 0.9479 & 80.6763 \\
\hline Trade rating & 370 & 3.6332 & 0.6997 & 0.0000 & 4.5000 \\
\hline Financial sector rating & 370 & 3.9885 & 17.3322 & 0.0000 & 305.000 \\
\hline Foreign direct investment & 370 & 5.7039 & 1.5864 & 2.2460 & 9.0966 \\
\hline Exchange rate & 370 & 5.6863 & 2.3301 & 2.3903 & 22.6288 \\
\hline Inflation (CPI, percent) & 370 & 1.9736 & 1.1732 & -2.5842 & 10.1028 \\
\hline
\end{tabular}

Table A2: Illicit outflows (average 10\% high \& 10\% low) by countries (2005-2014)

\begin{tabular}{|l|l|l|l|l|l|}
\hline Country & Misinvoicing & Leakages & Country & Misinvoicing & Leakages \\
\hline Angola & 819.1008 & ------ & Kenya & 236.6341 & -------- \\
\hline Benin & 180.8223 & ------- & Lesotho & 151.9863 & 130.8656 \\
\hline Burkina Faso & 596.1007 & 586.3589 & Liberia & 876.0241 & 707.7891 \\
\hline Burundi & 94.9463 & 55.8904 & Madagascar & 320.0328 & 235.7361 \\
\hline Cabo Verde & 46.2436 & 10.31509 & Malawi & 478.7565 & 415.8589 \\
\hline Cameroon & 530.5648 & 500.6716 & Mali & 396.5497 & 317.8178 \\
\hline Central African Republic & 29.7536 & ------- & Mauritania & 131.6396 & --------- \\
\hline Chad & 964.9859 & 867.3369 & Mozambique & 237.4515 & 181.9227 \\
\hline Comoros & 44.2375 & 43.30408 & Niger & 131.2475 & 91.80613 \\
\hline Congo, Democratic Republic of & 156.8112 & -------- & Nigeria & 17855.95 & 1750.675 \\
\hline Congo, Republic of & 1071.821 & 1033.868 & Rwanda & 173.1927 & 161.1524 \\
\hline Cote d'Ivoire & 1613.615 & 1576.626 & Senegal & 576.19 & 553.652 \\
\hline Eritrea & 33.95 & ------- & Sierra Leone & 156.8197 & 80.34997 \\
\hline Ethiopia & 2205.775 & 1637.046 & Sudan & 8905.085 & 8666.016 \\
\hline Gambia, The & 76.0940 & 33.41647 & Tanzania & 406.0419 & 28.53912 \\
\hline Ghana & 660.538 & -------- & Togo & 1708.457 & 1705.434 \\
\hline Guinea & 364.4901 & 324.4069 & Uganda & 527.693 & 400.6542 \\
\hline Guinea-Bissau & 34.35414 & 27.57689 & Zambia & 552.5114 & 490.9071 \\
\hline & & & Zimbabwe & 429.853 & --------- \\
\hline
\end{tabular}

